\title{
Mutagenesis of 18 Type III Effectors Reveals Virulence Function of $\mathrm{XopZ}_{\mathrm{Pxog9}}$ in Xanthomonas oryzae pv. oryzae
}

\author{
Congfeng Song ${ }^{1,2}$ and Bing Yang ${ }^{1}$ \\ ${ }^{1}$ Department of Genetics, Development and Cell Biology, lowa State University, Ames 50011, U.S.A.; ${ }^{2}$ Key Laboratory \\ of Monitoring and Management of Plant Diseases and Insects, Ministry of Agriculture, Nanjing Agricultural University, \\ Nanjing 210095, China
}

Submitted 27 January 2010. Accepted 2 March 2010.

Xanthomonas oryzae pv. oryzae depends on a type III secretion system (T3SS) to translocate effectors into host cells for its ability to cause bacterial blight of rice. All type III (T3) effectors with known function in $X$. oryzae pv. oryzae belong to a family of transcription activator-like (TAL) effectors. However, other, non-TAL-related effector genes are present in the genome, although their role in virulence and their mode of action have yet to be elucidated. Here, we report the generation of mutants for 18 non-TAL T3 effector genes and the identification of one that contributes to the virulence of strain PXO99. $\mathrm{XopZ}_{P X O 99}$ encodes a predicted 1,414-amino-acid protein of unknown function. PXO99 $^{\mathrm{A}}$ contains two identical copies of the gene due to a duplication of $212 \mathrm{~kb}$ in the genome. Strains with knockout mutations of one copy of $X o p Z_{P X O 99}$ did not exhibit any visible virulence defect. However, strains with mutations in both copies of $X o p Z_{P X O g 9}$ displayed reduced virulence in terms of lesion length and bacterial multiplication compared with PXO99A. The introduction of one genomic copy of $X o p Z_{P X O 9 g}$ restores the mutant to full virulence. Transient expression of $X o p Z_{P X O 99}$ in Nicotiana benthamiana leaves suppresses host basal defense, which is otherwise induced by a T3SS mutant of PXO99', suggesting a role for $X o p Z_{P X O 99}$ in interfering with host innate immunity during $X$. oryzae pv. oryzae infection. $X o p Z_{P X 099^{-}}$-related genes are found in all Xanthomonas spp. whose genomic sequences have been determined, suggesting a conserved role for this type of effector gene in pathogenesis of Xanthomonas spp. Our results indicate that $X o p Z_{P X O 99}$ encodes a novel T3 effector and contributes virulence to $X$. oryzae pv. oryzae strains for bacterial blight of rice.

Like many other gram-negative pathogenic plant bacteria, strains of Xanthomonas use the highly conserved type III secretion system (T3SS) to deliver a suite of substrate effectors, the so-called type III (T3) effectors, into their host cells (Zhu et al. 2000; Buttner and Bonas 2002, 2006). Generally, the interactions of T3 effectors and the host factors define the outcome of the diseases (Block et al. 2008). The T3 effectors, once internalized, function in host cells to either promote bacterial

Corresponding author: B. Yang; E-mail: byang@iastate.edu; Telephone: +1.515 .294 .2968 ; Fax: +1.515.294.5256

* The $\boldsymbol{e}$-Xtra logo stands for "electronic extra" and indicates that a supplementary table and two supplementary figures are published online. growth and disease development by interfering with the host cellular physiology (virulence function) or betray the pathogen, historically called an avirulence function, by triggering host defense responses, including the hypersensitive response (HR), through recognition of effector by the cognate resistance $(R)$ genes (Mudgett 2005; Grant et al. 2006; da Cunha et al. 2007). Although highly variable at the structural level in individual strains, most T3 effectors appear to function redundantly for virulence because loss of individual effector genes often has moderate or no detectable effects on virulence. At the same time, the genes must play a vital role in pathogenicity because loss of all, as in the case of a T3SS mutant, or a set of effector genes severely reduces the virulence of the pathogen (Guttman et al. 2002; Salanoubat et al. 2002; Cunnac et al. 2004, 2009; Gurlebeck et al. 2006; Kvitko et al. 2009). For those that exhibit observable virulence contribution, their function seems to interfere with the host defense processes that are related to the effector-triggered immunity (ETI) or pathogenassociated molecular pattern (PAMP)-triggered immunity (PTI) (Buttner and He 2009). The PTI is a process that involves recognition of pattern molecules of the pathogen by the host surface-associated kinase receptors and the subsequent triggering of a cascade of defense responses, leading to the restriction of pathogen spread (Chisholm et al. 2006). One aspect of PTI is the host cell-wall-associated defense, a process by which the host deposits callose on the cell wall in the vicinity of the infection site. The function of some T3 effectors has been found to interfere with the cell-wall-associated defense and visibly suppress callose deposition (Block et al. 2008).

The collection of T3 effectors in the bacteria of Xanthomonas are designated as Xanthomonas outer protein (Xop) and are classified into 39 families based on the sequence relatedness reflecting the genetic diversity of virulence weaponry in the pathogens (White et al. 2009). The transcription activatorlike (TAL) T3 effectors consist of the largest group of Xop effectors. Each TAL effector is characteristic of eukaryotic transcription activator and, in a few cases, has been shown to transcriptionally activate the corresponding host gene for host disease susceptibility or resistance (Gu et al. 2005; Yang et al. 2006; Sugio et al. 2007; Kay et al. 2007; Romer et al. 2007). Recent studies have revealed the recognition of specific DNA sequences within the promoters of host target genes by TAL effectors (Boch et al. 2009; Moscou and Bogdanove 2009). Several other types of Xop effectors have also been shown to play an important role in pathogenesis of Xanthomonas bacteria. AvrBs2 is the first Xop effector that has been shown to enhance bacterial multiplication within host tissue, a measur- 
able virulence contribution only observed in the strains of Xanthomonas campestris pv. vesicatoria (Kearney and Staskawicz 1990). AvrBs2, again, along with three other Xop effectors (AvrBs1, AvrBs3, and AvrBs4), has been demonstrated to benefit bacterial fitness in field conditions (Wichmann and Bergelson 2004). Furthermore, XopD and XopN are required for full virulence and involved in development of disease symptoms on susceptible plants in strains of $X$. campestris (Hotson et al. 2003; Jiang et al. 2008; Kim et al. 2008, 2009). XopD suppresses the expression of defense-related genes (Kim et al. 2008), and XopN has been shown to interact with a tomato atypical receptor-like kinase (TARK1) and to interfere with TARK1-associated defense process (Kim et al. 2009). The suppression of PTI by Xop effectors can also be manifested in suppressing the localized accumulation of callose and phenolics in papillae at the pathogen infection site. For example, the hrcC mutant of $X$. campestris pv. vesicatoria elicited callose deposition that could be suppressed by the wild-type bacterium in a T3SS-dependent manner, suggesting a role in callose sup-

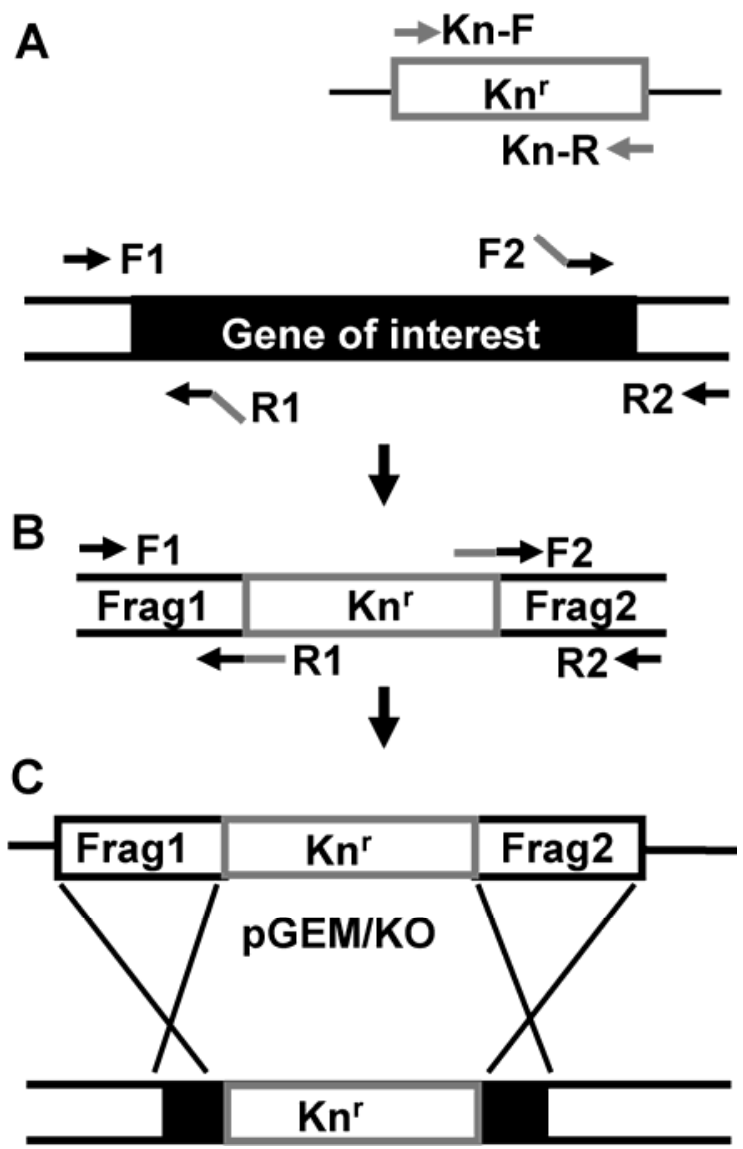

Fig. 1. Illustration of the strategy for mutagenesis. A, Three sets of primers are designed for three polymerase chain reaction (PCR) fragments. The pair of $\mathrm{Kn}-\mathrm{F}$ and $\mathrm{Kn}-\mathrm{R}$ is used to amplify the kanamycin resistance gene from plasmid pKD13. Primers F1 and R1 are gene specific and used for amplifying the $5^{\prime}$ portion of the gene of interest. The $3^{\prime}$ half of R1 (black arrow) is specific to the gene of interest and the $5^{\prime}$ half (gray line) is complementary to Kn-F, so that the sense strand of F1\&R1-derived PCR product functions as a long primer to extend over into kanamycin resistance $\left(\mathrm{Kn}^{\mathrm{r}}\right)$ when primer $\mathrm{R} 2$ and the PCR product of $\mathrm{Kn}-\mathrm{F} \& \mathrm{Kn}-\mathrm{R}$ are present in the second round of PCR. Similarly, F2 contains a $5^{\prime}$ half sequence (grey line) complementary to Kn-R and a $3^{\prime}$ half gene-specific sequence (black arrow). B, Three PCR fragments (Frag1, Frag2, and $\mathrm{Kn}^{\mathrm{r}}$ ) are fused into one fragment by overlap extension PCR using primer F1 and R2, resulting in part of the target gene being replaced by the kanamycin resistance gene. $\mathbf{C}$, The PCR product is cloned into the A/T vector pGEM-T (pGEM/KO) and the $\mathrm{Kn}^{\mathrm{r}}$ is exchanged into the place of the gene of interest in the genome through homologous recombination. pression for the Xop effectors in the strain (Keshavarzi et al 2004). More specifically, XopN and XopJ have been demonstrated to suppress defense-related callose deposition (Bartetzko et al. 2009; Kim et al. 2009).

The expression of the T3SS and its substrate effectors is highly coordinated for optimal fitness of the pathogen (Buttner and Bonas 2002; Cho et al. 2008). In Xanthomonas spp., the expression of a majority of T3 effector genes is controlled by the $h r p G / h r p X$ network through the recognition of a consensual cis element, called plant-inducible promoter (PIP) box, within the promoters of the effector genes (Cho et al. 2008). The coordinated expression of many T3 effector genes in Xanthomonas spp. can be mimicked by growing bacteria in an artificial minimum medium (Tsuge et al. 2002).

$X$. oryzae pv. oryzae is the causal agent of bacterial blight of rice, a devastating rice disease in Asia and west Africa (Mew 1987). Considerable research has been devoted to the identification of TAL effectors and the elucidation of their mode of action in causing the bacterial blight of rice. Each $X$. oryzae pv. oryzae strain contains a large repertoire of TAL effector genes, some of which are critical for virulence and others of which appear to have more moderate or contextual functions in virulence (White and Yang 2009). However, little is known regarding the content and contribution of non-TAL effectors in $X$. oryzae. Sixteen candidate Xop effectors were identified by screening the sequenced genome of the Japanese $X$. oryzae pv. oryzae MAFF311018. Of the 16, 4 effectors were unique to $X$. oryzae pv. oryzae and 12 were homologous to the known effectors in other species of plant-pathogenic bacteria (Furutani et al. 2009). Here, we report the identification and mutation analyses of 18 Xop effectors from the Philippine strain PXO99 ${ }^{\mathrm{A}}$ and the detailed characterization of one effector, $X o p Z_{P X O 99}$.

\section{RESULTS}

Strategy for the genetic analysis

of Xop genes in X. oryzae pv. oryzae.

We chose the Philippine strain PXO99A the most genetically tractable and best-characterized strain among $X$. oryzae pv. oryzae isolates, to generate a collection of mutants for all known and candidate Xop effector genes by using a marker exchange and gene deletion technique adapted for $X$. oryzae. The technique involves the polymerase chain reaction (PCR) amplification of two homologous fragments (approximately 500 bp) upand downstream of the coding region of the target gene, as well as an expression cassette of a selection marker gene (the neomycin phosphotransferase II gene for kanamycin resistance in this study) (Fig. 1A). The three PCR fragments are fused into one fragment by overlap PCR, resulting in the replacement of a portion of the gene coding sequence with the selection marker gene (Fig. 1B). The PCR product is then cloned into pGEM-T (Promega Corp., Madison, WI, U.S.A.) and confirmed with multiple restriction digestions or sequencing analysis (Fig. 1C). pGEM-T is a narrow-host-range plasmid and does not replicate in $X$. oryzae pv. oryzae. The resulting plasmid DNA is electroporated into PXO99 ${ }^{\mathrm{A}}$ cells and the transformants are selected on trypton sucrose (TS) or nutrient broth (NB) medium supplemented with kanamycin. The kanamycin-resistant clones are further screened for ampicillin sensitivity indicative of double-crossover events of homologous recombination (Fig. 1C). The kanamycin-resistant and ampicillin-sensitive clones are chosen for further characterization.

\section{Identification of 18 non-TAL effector genes in PXO99 ${ }^{\mathrm{A}}$.}

Through PCR, the identities of 13 previously identified nonTAL effector genes were confirmed to be present in PXO99 ${ }^{\mathrm{A}}$ (Furutani et al. 2009). An additional five effector genes were 
identified based on the information from the database of the Xanthomonas Resource. In total, we confirmed the existence of 18 non-TAL effector genes in PXO99 ${ }^{\mathrm{A}}$ genome (Table 1). Among them, the open reading frames (ORF) of 11 genes from the annotated PXO99 ${ }^{\mathrm{A}}$ genome (National Center for Biotechnology Information accession number CP000967) were reannotated based on the presence and position of the PIP sequence and of the -35 and -10 sequences upstream of the translation start site of each gene, as well as based on comparisons with their homologues in other bacteria. The reannotated genes contained varying numbers of additional coding sequences extending from the initially annotated translation start codons, and included two newly assigned effector genes due to their apparent homology to those in other sequenced Xanthomonas strains (Table 1). Two identical effector loci (PXO_01041 and PXO_06152) are pre- sent in PXO99 A due to a duplication of a 212-kb genomic region (Salzberg et al. 2008), and are members of the XopZ effector family (designated individually as XopZ-1 $1_{\mathrm{PXO} 9}$ and XopZ$2_{\text {PXO99, collectively as XopZ }}$ PXO99). Among the 18 effectors, XopU, XopW, XopY, and XopAB are unique to X. oryzae.

\section{Mutagenesis of 18 Xop effector genes in PXO99 ${ }^{\mathrm{A}}$.}

Using the eviction strategy outlined above, mutants for each of 18 effector genes were constructed. The primers specific to the sequences upstream and downstream of the ORF are provided in Supplementary Table S1. Mutants of each gene were confirmed by comparing the size of PCR product from the wild type with that from the mutated allele containing the kanamycin expression cassette (Fig. 2, upper panel). Gene replacements and deletions were further confirmed by PCR using primers corre-

Table 1. Genes used for mutagenesis and virulence test in this study

\begin{tabular}{|c|c|c|c|}
\hline Gene ID & Effector class & CDS coordinate $^{a}$ & PIP box ${ }^{b}$ \\
\hline PXO_03330 & AvrBs2 & compl:154939..157083* & TTCGC-N $15^{-}$TTCGC \\
\hline PXO_02108 & ХорС & $3794998 . .3796245$ & No \\
\hline PXO_03413 & $\mathrm{XopF}$ & $63828 . .65531 *$ & TTCGT-N $_{15}$-TTCGC \\
\hline PXO_01625 & XоpK & compl:3280493..3277851* & TTCGT-N 15 -TTCGT \\
\hline PXO_01620 & XopL & $3283191 . .3285161$ & TTCGC-N $_{15}$-TTCGC \\
\hline PXO_02760 & XopN & comp:5035158..5037362* & TTCGG-N 15 -TTCGG \\
\hline PXO_02107 & ХорР & compl:3796473..3798956 & TTCGT-N 15 -TTCGC \\
\hline PXO_03901 & XopQ & $336104 . .337498 *$ & TTCGT-N $15^{-T T C A C}$ \\
\hline PXO_03819 & XopR & $424474 . .425787$ & TTCGG-N ${ }_{15}$-TTCGC \\
\hline PXO_00236 & XopU & compl:1628549..1631629 & TTCGC-N $15^{-}$TTCGG \\
\hline PXO_04172 & XopV & compl:838059..838925* & TTCGC-N 15 -TTCTG \\
\hline PXO_03356 & XopW & $129538 . .129861$ & TTAAA- $N_{15}$-TTGAA \\
\hline PXO_03702 & XopX & compl:526158..528347* & TTCTG-N 15 -TTCGC \\
\hline PXO_04866. $1^{\mathrm{c}}$ & XopY & compl:1513133..1513978 & TTCGC-N $_{15}$-TTCGC \\
\hline PXO_06152 & XopZ & $2559627 . .2563871^{*}$ & TTCTC-N 15 -TTCGC \\
\hline PXO_01041 & XopZ & $2771714 . .2775958^{*}$ & TTCTC-N 15 -TTCGC \\
\hline PXO_00234 & XopAA & compl:1633529..1635616 & No \\
\hline PXO_01868.1 ${ }^{\mathrm{d}}$ & XopAB & $3708124 . .3708678 *$ & TTTCA-N $_{15}$-TTGTC \\
\hline PXO_03833 & XopAD & 400976..409759* & TTCGC-N $_{15}$-TTCGT \\
\hline
\end{tabular}

${ }^{a}$ Asterisk (*) indicates that CDS coordinates have been changed according to manual reannotation with varying numbers of coding nucleotides extending at $5^{\prime}$ ends.

${ }^{\mathrm{b}} \mathrm{PIP}=$ plant-inducible promoter.

c PXO_04866.1 was not annotated by Salzberg and associates (2008) but is identical to XOO_1488 of strain MAFF 311018 and overlaps PXO_04866.

${ }^{\mathrm{d}}$ PXO_01868.1 was not annotated by Salzberg and associates (2008) but is identical to XOO_3150 of strain MAFF 311018. The open reading frame is immediately downstream of PXO_01868.

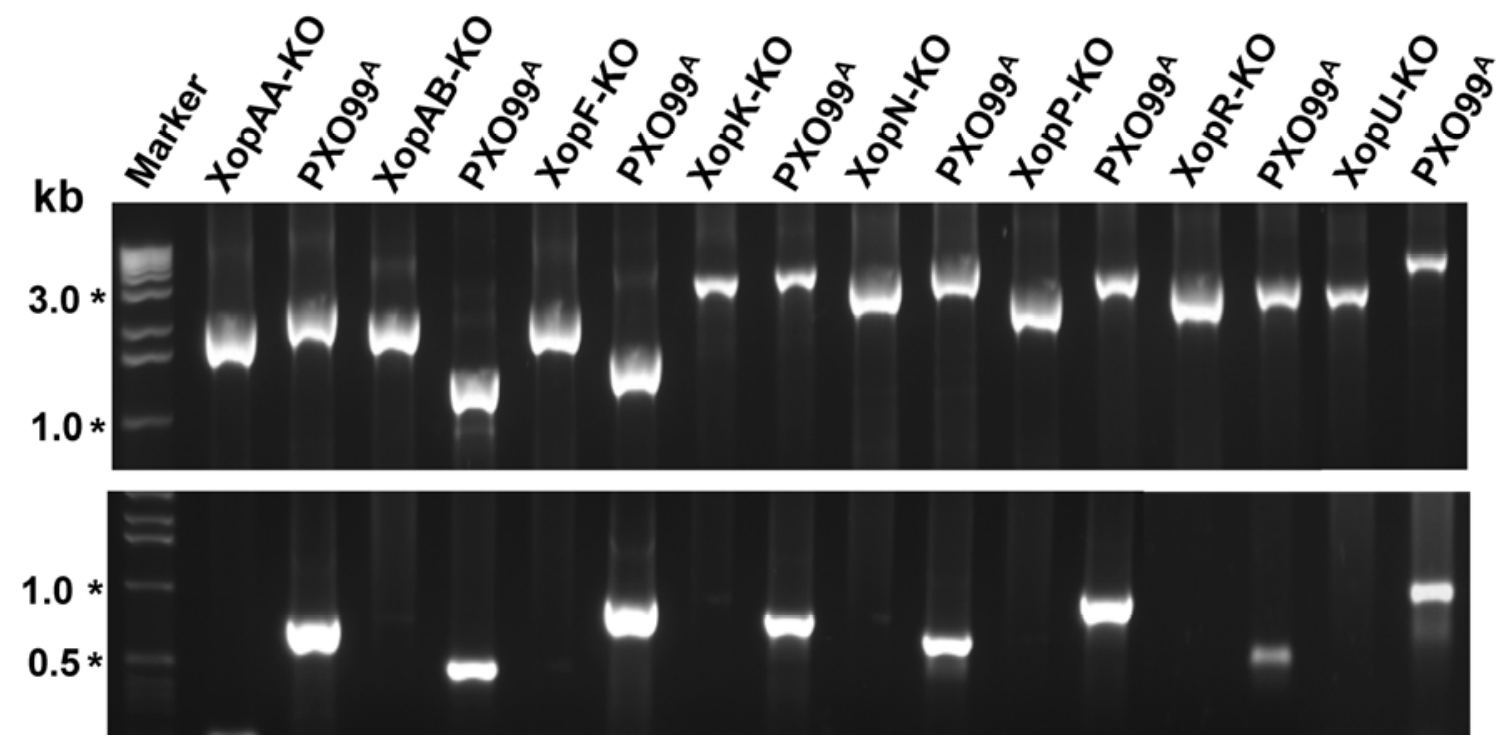

Fig. 2. Validation of gene deletion. Genomic DNA of the mutants for individual genes and the wild-type strain PXO99 (as indicated above individual lanes) was subjected to polymerase chain reaction (PCR) using the primers corresponding to F1 and R2 of each gene (upper image of DNA gel stained with ethidium bromide). The respective DNA was also used for PCR with the internal primers between R1 and F2 of each gene (lower panel). The gel images of PCR products derived from the mutants of eight genes are presented. The DNA marker was loaded in the first lanes, and the size of four bands was denoted at the left sides of the gels. 
sponding to the coding regions that were expected to be deleted (Fig. 2, lower panel). Each mutant was then tested for virulence assay using the leaf-tip-clipping method (Kauffman et al. 1973). The lesion lengths caused by the mutants of 17 genes except $X o p Z_{P X O 99}$ were not significantly shorter than those caused by the wild-type strain PXO99A (data not shown). The mutagenesis and function analysis of $X o p Z_{P X O 99}$ are presented in detail below.

$X o p Z_{P X 099}$ is required for the full virulence of $P X O 99^{\mathrm{A}}$.

PXO99A contains two identical loci of XopZ $Z_{P X O 99}$ (Fig. 3A). Seventy-three clones of PXO99 ${ }^{\mathrm{A}}$ were derived with the construct of pKn-XopZ (Fig. 3B). Analysis of the clones indicated that 4 of the 73 were ampicillin sensitive (referred to as MX1, MX6, MX15, and MX24) and were further analyzed by PCR for gene replacement and deletion. Analysis of MX6 and MX15 indicated that only one copy of $X o p Z_{P X O 99}$ was replaced, as evidenced by the presence of two bands, which represent the 4.3-kb band of the genomic region of the wild-type strain $\mathrm{PXO}^{\mathrm{A}}{ }^{\mathrm{A}}$ and the expected replacement band of $2.5 \mathrm{~kb}$ (Fig. 3C, upper panel).

\section{A}

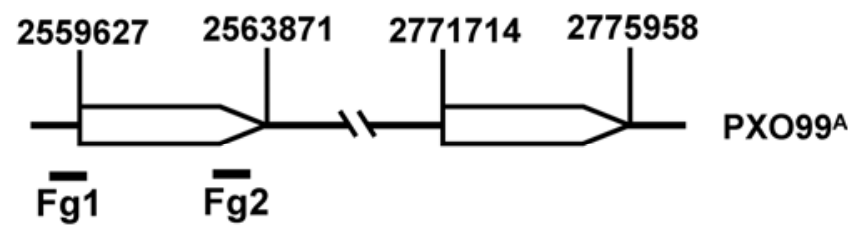

B
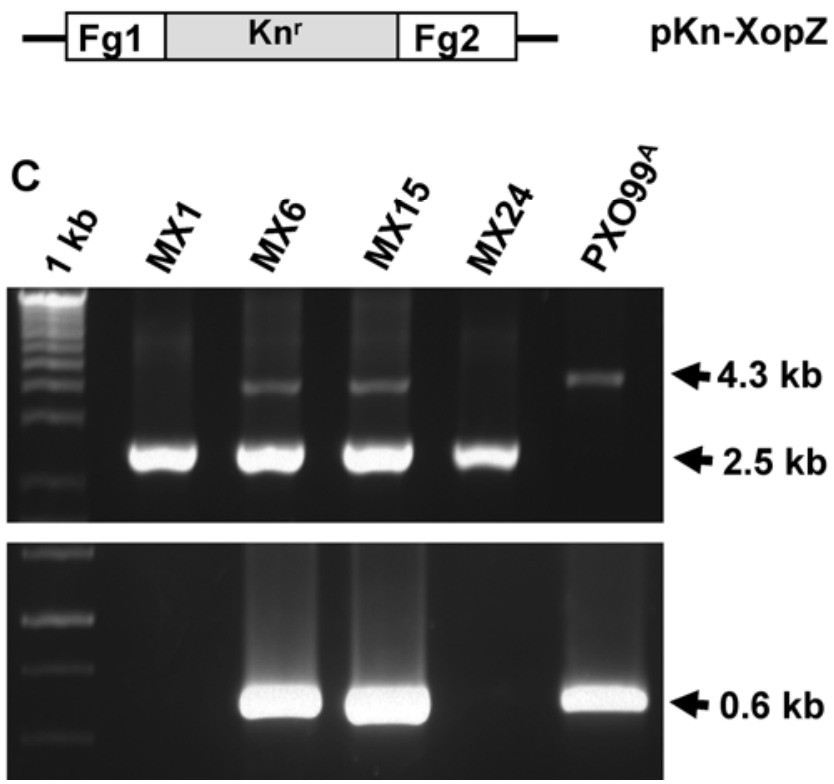

Fig. 3. Characterization of $X o p Z_{P X O 99}$ knockout mutations. A, Sequenced PXO99 ${ }^{\mathrm{A}}$ contains two identical copies of $X o p Z_{P X O 99}$ at two locations (2,559,627 to $25,638,871 \mathrm{bp}$ and $2,771,714$ to $2,775,958 \mathrm{bp})$. B, Two polymerase chain reaction (PCR) fragments $(\mathrm{Fg} 1$ and $\mathrm{Fg} 2)$ are joined with the neomycin phosphotransferase II (NPTII) gene by overlap PCR and cloned into pGEM-T to generate $\mathrm{pKn}-\mathrm{XopZ}$, which is nonreplicable and able to marker exchange with the $X o p Z_{P X O 99}$ locus or loci, leading to the deletion of a 3,198-bp XopZ $Z_{P X O 99}$ coding sequence in PXO99A C, Four kanamycinresistant and ampicillin-sensitive clones (as indicated above each lane) were subjected to PCR using primers corresponding to F1 and R2 of $X o p Z_{P X 099}$. The expected size of PCR product was $4.3 \mathrm{~kb}$ for unchanged $X o p Z_{P X O 99}$ and $2.5 \mathrm{~kb}$ for kanamycin replacement (upper panel). Two $X o p Z_{P X O 99}$-specific primers located between Fg1 and Fg2 were used to detect the deletion of the corresponding region (lower panel). The DNA marker $(1 \mathrm{~kb})$ was loaded in the first lane. The size of the PCR product in the ethidium bromide-stained gel was indicated at the right side.
The one wild copy gene in MX6 and MX15 was also identified by the presence of an internal $0.6-\mathrm{kb}$ fragment corresponding to the coding region that was expected to be replaced (Fig. 3C, lower panel). MX1 and MX24, on the other hand, had mutations with both copies of $X o p Z_{P X O 99}$, as evidenced by the presence of only the $2.5-\mathrm{kb}$ fragment and the absence of either $4.3-$ or $0.6-\mathrm{kb}$ bands of the wild-type gene (Fig. 3C). All four clones were morphologically indistinguishable from the wild type and did not show any growth defect in TS or NB medium. The lengths of leaf lesion caused by MX6 and MX15 were not significantly different from the lesion length caused by wild-type strain PXO99 ${ }^{\mathrm{A}}$ (data not shown). However, MX1 caused shorter lesion lengths on susceptible rice leaves than PXO99 ${ }^{\mathrm{A}}$ (Fig. 4A, columns PXO99A $^{A}$ versus MX1), and the bacterial populations of MX1 were approximately fivefold lower than those of PXO99 ${ }^{\mathrm{A}}$ (Fig. 4B). Results for MX24 were similar (data not shown).

\section{Reduced virulence of MX1 was restored} to wild-type levels by cloned $X o p Z_{P X O g g}$.

Functional complementation tests were performed with reintroduction of $X o p Z_{P X O 99}$ to confirm if the virulence reduction was due to the loss of $X o p Z_{P X O 99}$ in the mutants MX1 and MX24. The genomic region with the predicted translation start site and stop codon of $X o p Z_{P X O 99}$ was PCR amplified and sub-
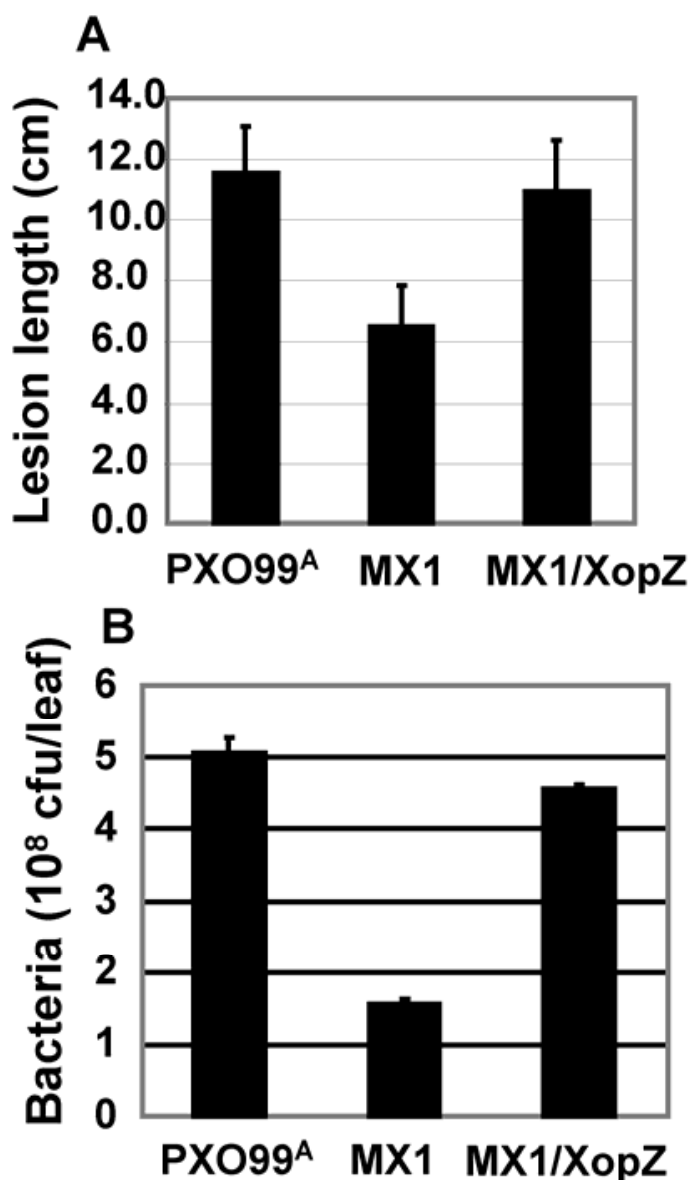

Fig. 4. Virulence assay on the $X o p Z_{P X O 99}$ mutant and its complementing strains. A, Measurements of lesion lengths caused by PXO99 ${ }^{\mathrm{A}}, \mathrm{MX} 1$, and MX1 harboring a 6.3-kb genomic fragment of $X o p Z_{P X O 99}$ in pHM1 (as indicated under each column) were presented. The measurements each were obtained from 10 leaves of five rice plants (two leaves per plant). B, Bacterial populations of the indicated strains under each column were each obtained from a pool of five plants (two leaves each plant) and manifested as CFU per leaf. The virulence assays for lesion length and bacterial population were carried out on 4-week old IR24 leaves 12 days after inoculation and were repeated at least twice with similar results. 
cloned under the promoter of the neomycin phosphotransferase II (NPTII) gene in pHM1. Upon addition of the resulting gene construct, both MX1 and MX24 caused lesion length on rice leaves similar to that caused by $\mathrm{PXO}^{\mathrm{A}}$ (data not shown). Similarly, a single genomic region of $6.3 \mathrm{~kb}$, including $1.5 \mathrm{~kb}$ upstream of the translation start site and $0.5 \mathrm{~kb}$ downstream of the stop codon, was amplified and cloned into broadhost-range vector pHM1. The clone was introduced into MX1 (pHMI-XopZ) and tested for virulence in rice leaves. The strain recovered in virulence, as indicated by the lesion length and leaf population, compared with MX1 (Fig. 4).

\section{Inducible expression of $X^{X p p Z} Z_{P X O 99}$ is HrpG dependent.}

Sequence analysis of $X o p Z_{P X O 99}$ revealed a consensus sequence of a PIP box (TTCTC-N15-TTCGC) 58 bp upstream of the predicted translation start site, indicative of a gene that is inducible in planta and regulated through the hypersensitive reaction and pathogenicity ( $h r p$ ) regulatory network (Fig. 5A). To test this possibility, expression of Xop $Z_{P X O 99}$ was investigated with reverse-transcription (RT)-PCR from the RNA from PXO99 ${ }^{\mathrm{A}}$ and an hrpG mutant grown in NB or Xanthomonas $h r p$-inducing medium (XOM2). Expression of $X o p Z_{P Х O 99}$ was only observed in XOM2 medium and was $\operatorname{hrpG}$ dependent (Fig. 5B).

XopZ $Z_{P X 099}$ suppressed plant cell-wall-related PTI.

A variety of $\mathrm{T} 3$ effectors in bacterial plant pathogens have been found to suppress PTI, including the cell-wall-based defense responses involving callose deposition at the inoculation site (Block et al. 2008). To test whether $X o p Z_{P X O 99}$ also inhibits
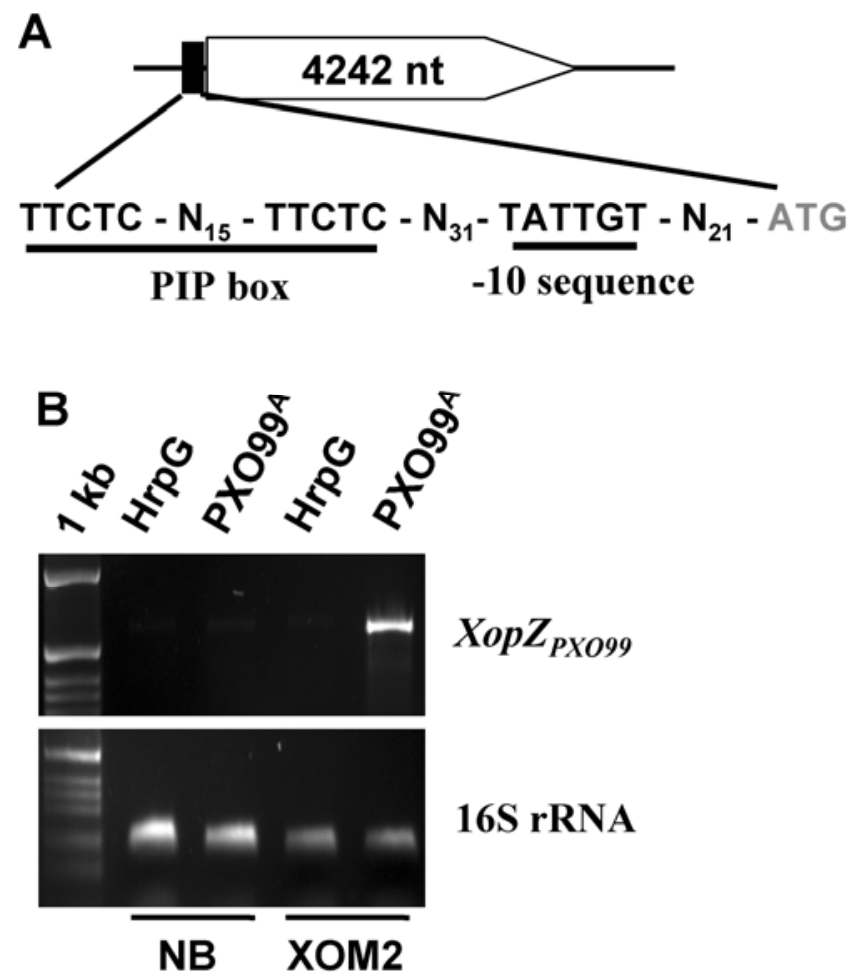

Fig. 5. Gene structure and expression of $X o p Z_{P X O 99 .}$. A, Xop $Z_{P X O 99}$ contains a consensus sequence of a plant-inducible promoter (PIP) box and an open reading frame of 4,242 nucleotides coding region. B, Xop $Z_{P X O 99}$ is induced in minimum medium, and the induction is dependent on $h r p G$. The mRNA of PXO99 ${ }^{\mathrm{A}}$ (lane 2) and the $h r p G$ mutant (lane 1) grown in nutrient broth (NB) and hrp induction medium (XOM2), respectively, was used for semiquantitative reverse-transcription polymerase chain reaction with primers specific to XopZ $Z_{P X O 99}$ (upper panel) and the Xanthomonas oryzae pv. oryzae $16 \mathrm{~S}$ ribosomal RNA gene (lower panel, as an internal control).

the host cell-wall-associated defense responses, the ability of a PXO99A ${ }^{\mathrm{A}}$ TSS-deficient strain (ME7) to induce callose accumulation upon inoculation on the leaves of Nicotiana benthamiana was examined. Leaves of $N$. benthamiana were infiltrated with Agrobacterium cells with and without $X o p Z_{P X O 99}$ under the control of the Cauliflower mosaic virus $35 \mathrm{~S}$ promoter $24 \mathrm{~h}$ preceding inoculation of the same leaves with ME7. The Agrobacterium spp. containing the construct of green fluorescent protein (GFP) in place of $X o p Z_{P X O 99}$ was used as a control. Twenty-four hours after ME7 inoculation, leaf disks were collected and stained for the appearance of callose deposition. Leaves inoculated with ME7 and prior infiltration with Agrobacterium spp. expressing GFP had more callose depositions than the leaves with the prior infiltration of Agrobacterium spp. expressing $X o p Z_{\text {РХO99 }}$ (Fig. 6).

\section{XopZ family members are} among several species of bacterial pathogens.

XopZ homologs of varying degrees of similarity have been found in all strains of Xanthomonas for which genome sequence data is available. Related genes are also found in several Pseudomonas syringae pathovars (HopAs1 relatives), a few strains of Ralstonia solanacearum (AWR proteins), and the AAC00-1 strain of Acidovorax avenae subsp. citrulli, a causal agent of bacterial fruit blotch of cucurbits (Willems et al. 1992) (Fig. 7). Phylogenetic analysis of known family members reveals three subgroups of XopZ. Xop $Z_{P X O 99}$ is 98 to $100 \%$ identical to three other members from the sequenced strains of $X$. oryzae; ap-

A

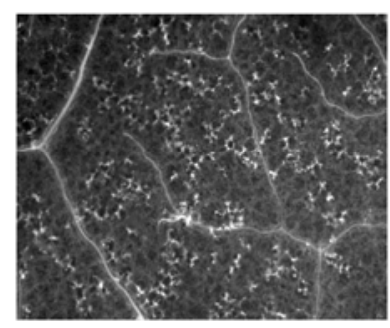

B
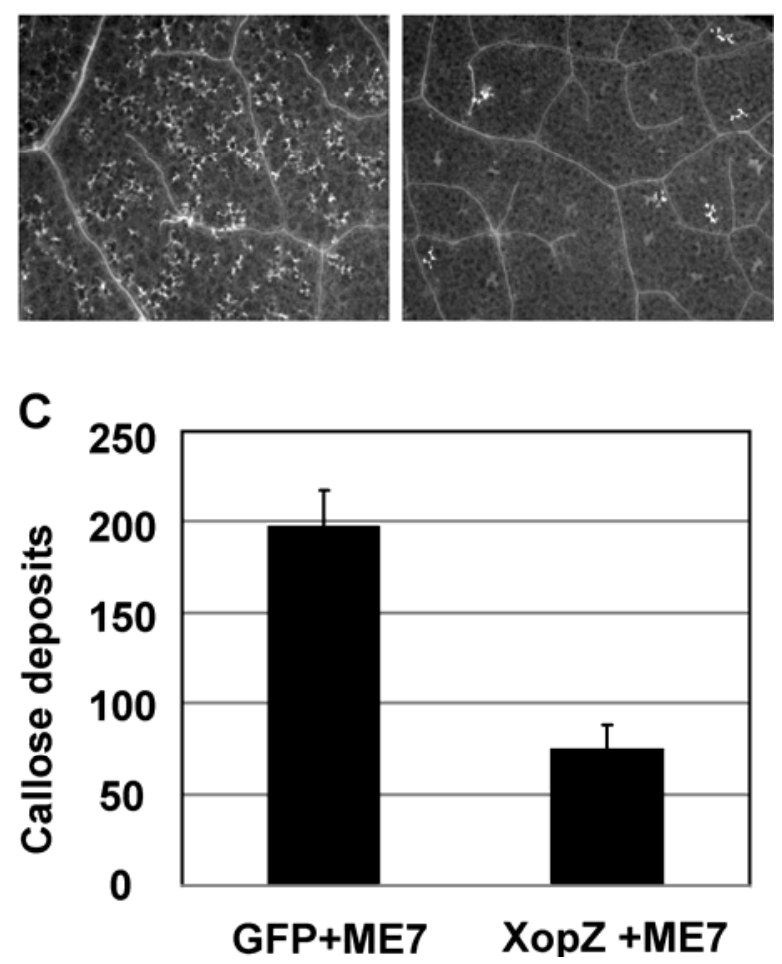

Fig. 6. $X o p Z_{P X O 99}$ suppresses plant cell-wall-associated callose deposition when ectopically expressed. Nicotiana benthamiana leaves were stained with aniline blue for callose (white dots in A and B) $24 \mathrm{~h}$ after inoculation of ME7 (PXO99 ${ }^{\mathrm{A}}$ hrpC mutant). A, Leaves were pretreated with Agrobacterium tumefaciens containing green fluorescent protein (GFP) expressing construct $24 \mathrm{~h}$ prior to ME7 inoculation. B, Leaves were pretreated with $A$. tumefaciens containing $X o p Z_{P X O 99}$ under Cauliflower mosaic virus $35 \mathrm{~S}$ promoter $24 \mathrm{~h}$ prior to ME7 inoculation. C, Quantitation of callose deposits per leaf disk $\left(38 \mathrm{~mm}^{2}\right)$ in A and B. Data were from the counting of 10 leaf disks. 
proximately 82 to $84 \%$ identical to those from $X$. campestris pv. campestris, $X$. campestris pv. vesicatoria, and $X$. axonopodis pv. citri pathovars; and approximately 20 to $30 \%$ identical to the third subgroup occurring in the sequenced $P$. syringae and $R$. solanacearum pathovars (Fig. 7).

\section{DISCUSSION}

PXO99 $^{\mathrm{A}}$ is an excellent model strain for studying the molecular interaction between $X$. oryzae pv. oryzae and its host, rice. This work further enhanced the system by our demonstration that the strain is amenable to manipulation using gene deletion and replacement technology. We utilized the technology to investigate the non-TAL Xop effector genes in $X$. oryzae, which have drawn little attention in the past decades. Based on genome information, 18 such effector genes in PXO99 ${ }^{\mathrm{A}}$ were identified as candidate targets. Mutation of both copies of $X o p Z_{P X O 99}$ alone affected the strain's ability to cause virulence in rice relative to the parental strain $\mathrm{PXO} 99^{\mathrm{A}}$ using our standard leaf-clip and leaf-population assays, making $X o p Z_{P X O 99}$ the only non-TAL effector gene in $X$. oryzae pv. oryzae with a known contribution to virulence.

Considerable efforts have been focused on TAL effectors due to their intriguing characteristics of transcription factors and clear phenotypic effects on the pathogenicity of various $X$. oryzae pv. oryzae strains. A large number of TAL effector genes in each genome are characteristic of $X$. oryzae strains, and a few have been studied extensively in $X$. oryzae $\mathrm{pv}$. oryzae, especially in PXO99 (White and Yang 2009). PthXo1 is an essential virulence gene for PXO99 ${ }^{\mathrm{A}}$, while PthXo6 and PthXo7 each play a moderate role in strain virulence (Yang and White 2004; Sugio et al. 2007). PXO99 ${ }^{\mathrm{A}}$ also harbors two
TAL effector genes, avrXa27 and avrXa23, whose products elicit resistance in combination with their cognate $R$ genes, $\mathrm{Xa27}$ and $\mathrm{Xa23}$, respectively (Gu et al. 2005; Wang et al. 2008). By contrast, little is known about the identity and role of non-TAL effectors for pathogenicity in $X$. oryzae pv. oryzae strains, although the genomes of three $X$. oryzae pv. oryzae strains have been sequenced and annotated (Lee et al. 2005; Ochiai et al. 2005; Salzberg et al. 2008; Furutani et al. 2009). Based on genomic analyses and cataloging of Xop effectors from other strains, 18 non-TAL effectors or candidates belonging to 18 of the classified 39 Xop families in PXO99 ${ }^{\mathrm{A}}$ have been identified in this study. The majority of them are T3 effector genes whose counterparts in the Japanese strain MAFF 311018 have been shown to be regulated by the Hrp regulatory factor HrpX and translocated into plant cells in the adenylate cyclase assays (Furutani et al. 2009). However, three are candidate effector genes for the lack of evidence in their functional secretion or translocation. Among them, XopL and $X o p A D$ each contain a PIP box sequence in the promoter regions and lack one for XopC (Table 1).

Most of these non-TAL effector genes did not exhibit phenotypes in virulence when individually mutated in $\mathrm{PXO}^{\mathrm{A}}$, which is consistent with the results of previous works on mutagenesis of a complement or a subset of T3 effector genes in other plant bacterial pathogens. Mutations of seven Xop effector genes individually in $X$. campestris pv. vesicatoria resulted in only one with a notable phenotypic effect on the pathogenicity in a susceptible plant (Roden et al. 2004). The mutants with eight Xop effector genes deleted individually or collectively did not show any alteration in pathogenicity compared with the wild X. campestris pv. campestris $528^{\mathrm{T}}$ on the susceptible host plants (Castaneda et al 2005). Similar results

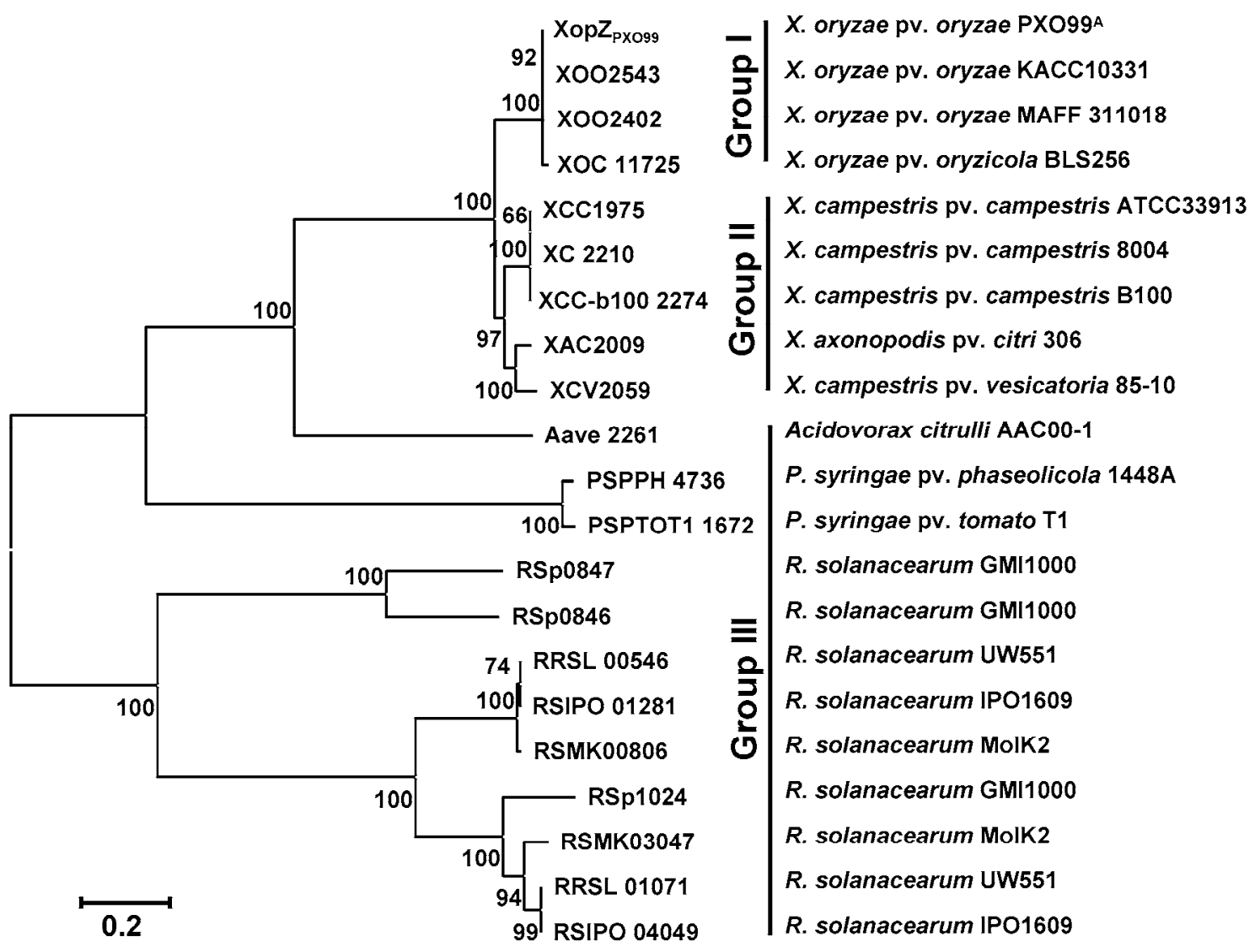

Fig. 7. Unrooted phylogenic tree of XopZ. Bootstrap values shown at nodes were obtained from 1,000 trials, and branch lengths correspond to the divergence of sequences, as indicated by the relative scale ( $20 \%$ weighted sequence divergence). Sequence designations refer to locus tag corresponding to their accession number in the database. The origin of each homologue (bacterial strain) is indicated at the right side. 
with other pathosystems also revealed the dispensable role of the individual T3 effector genes in pathogenesis (Cunnac et al. 2004; Kvitko et al. 2009). The functional overlap of multiple effectors in one strain appears to be a major factor that prevents detecting obvious phenotypic effect on host reaction. However, the function of such individual effectors can be revealed in heterogeneous systems that contain few functional effectors. For example, the majority of the $35 \mathrm{~T} 3$ effectors that have been found in Pseudomonas spp. could suppress an HR, although few had previously been demonstrated to contribute to strain virulence (Guo et al. 2009).

The $X o p Z$ effector gene family consists of those from strains of $X$. oryzae and $X$. campestris, two pathovars of $P$. syringae, four strains of $R$. solanacearum, and one A. citrulli strain, suggesting a broad contribution to pathogenicity of those bacterial strains. The function of other members for virulence or avirulence needs further investigation. The contribution of XopZ could, in fact, be potentially greater and may be partially masked by other functionally redundant effector genes in PXO99 ${ }^{\mathrm{A}}$ and other strains. It is also possible that the sensitivity of the phenotypic effect of mutation of $X o p Z$ in other strains is different from $\mathrm{PXO} 99^{\mathrm{A}}$. Likewise, we did not observe obvious phenotypic change associated with the mutation of the XopN homologous gene in PXO99 ${ }^{\mathrm{A}}$, although two members of XopN were found to be required for full virulence in the strains of $X$. campestris (Jiang et al. 2008; Kim et al. 2009). The other cases of difference are XopX and avrBs2 homologues in PXO99 ${ }^{\mathrm{A}}$. XopX was found to be a virulence effector of the $X$. campestris pv. vesicatoria GM98-38 on host pepper and tomato plants, and to suppress host defense and promote disease susceptibility when ectopically expressed in $N$. benthamiana (Metz et al. 2005). Similarly, AvrBs2 has been found to be a virulence factor widespread among the pathogenic Xanthomonas strains of pepper plants (Gassmann et al. 2000). The results here are consistent with previous genetic analysis of $a v r B s 2$ in $\mathrm{PXO} 99^{\mathrm{A}}$, which also found no phenotypic contribution by $a v r B s 2$ to virulence (Mazzola et al. 1994).

The required complement of $\mathrm{T} 3$ effector genes from $X$. oryzae pv. oryzae, notably from the best genetically studied strains, has to be identified. Efforts also need to be made to elucidate the importance in effector-mediated pathogenesis and the underlying mechanisms for disease susceptibility and resistance of the host. It is likely that rice possesses a PTI system to fend off infection by a wide range of pathogenic microbes, although how similar the system is to the system in Arabidopsis remains to be shown (Boller and Felix 2009). Rice OsFLS2, an ortholog of AtFLS2 and a component of PTI pathways in Arabidopsis, responds to flagellin that is derived from the rice-incompatible pathogen $A$. avenae, and recognition subsequently triggers the innate immunity (Takai et al. 2008). Xa21, another AtFLS2 ortholog in rice, can specifically recognize Ax21, a small peptide associated with the $X$. oryzae pv. oryzae type I secretion system, and confer host resistance to strains containing functional Ax21 (Lee et al. 2009). Furthermore, a large repertoire of protein kinases exist in the rice genome, including many cell-surface-associated receptor-like kinases (RLK), some of which have been shown to be involved in perception of pathogen-conserved molecules in other plants (Boller and Felix 2009; Ding et al. 2009). Pathogenic $X$. oryzae pv. oryzae strains can deploy an arsenal of virulence factors, including Xop effectors, to disarm the RLK-mediated PTI. The detectable suppression of the host PTI or ETI by the Xop effectors in $X$. oryzae pv. oryzae needs to be elucidated. Our understanding of Xop effector-mediated virulence in bacterial blight of rice may provide insight into strategies to exploit disease susceptibility pathways for the broad and durable resistance to not just $X$. oryzae pv. oryzae but also other Xanthomonas plant pathogens, given that they share the conserved Xop effector repertoire.

\section{MATERIALS AND METHODS}

\section{Bacterial strains, plasmids, and DNA manipulations.}

Strains of Escherichia coli and $X$. oryzae pv. oryzae and plasmids used in this study are listed in Table 2. Standard bacterial culture and DNA techniques were used for $E$. coli and recombinant DNA manipulations (Ausubel et al. 1993). $X$. oryzae pv. oryzae was grown in either NB (Difco Laboratories, Detroit) or trypton sucrose (TS) medium (tryptone, $10 \mathrm{~g}$; sucrose, $10 \mathrm{~g}$; glutamic acid, $1 \mathrm{~g}$; Difco Bacto agar, if solid, $15 \mathrm{~g}$ per liter) at $28^{\circ} \mathrm{C}$. Plasmids were transformed into $E$. coli and $X$. oryzae pv. oryzae by electroporation. Antibiotics used in this study were ampicillin $(100 \mu \mathrm{g} / \mathrm{ml})$, cephalexin $(10 \mu \mathrm{g} / \mathrm{ml})$, kanamycin $(50 \mu \mathrm{g} / \mathrm{ml})$, and spectinomycin $(100 \mu \mathrm{g} / \mathrm{ml})$.

\section{Construction of mutants for 18 PXO99A effector genes.}

The three pairs of gene-specific primers for each of 18 effector genes were obtained from Integrated DNA Technologies (Iowa City, Iowa, U.S.A.). Standard PCR procedures were used, with the annealing temperature and extension time tailored for individual primer sets. Overlapping extension PCR was used to replace a portion of target gene in $\mathrm{PXO} 99^{\mathrm{A}}$ with a kanamycin resistance cartridge (Fig. 1). Briefly, PXO99 ${ }^{\mathrm{A}}$ genomic DNA was used as template, and a set of primers was used to amplify the $5^{\prime}$ region (amplicon Frag1), and another set of primers was used to amplify a fragment (amplicon Frag2) at the $3^{\prime}$ end of the target gene. The primers Kn-F and Kn-R were

Table 2. Bacterial strains and plasmids used in this study

\begin{tabular}{|c|c|c|}
\hline Designation & Genotypes or relevant characteristics $^{a}$ & Source or reference \\
\hline \multicolumn{3}{|l|}{ Plasmids } \\
\hline pGEM-T & Resistance to carbenicillin $\left(\mathrm{Cb}^{\mathrm{r}}\right)$ & Promega Corp. \\
\hline pKD13 & Resistance to kanamycin $\left(\mathrm{Kn}^{\mathrm{r}}\right)$ & Datsenko and Wanner 2000 \\
\hline pHM1 & Broad host range, spectinomycin resistant, polylinker, cos site & Hopkins et al. 1992 \\
\hline pXopZ-KD & $\mathrm{Kn}^{\mathrm{r}}$ flanked by $X o p Z_{P X O 99}$ fragments & This study \\
\hline pHM1/XopZ & 6.3-kb Xop $Z_{P X O 99}$ in pHM1 & This study \\
\hline $\mathrm{pHM} 1 / \mathrm{XopZ}_{\mathrm{c}}^{\mathrm{g}}$ & Xop $Z_{P X O 99}$ under NPTII promoter in pHM1 & This study \\
\hline \multicolumn{3}{|l|}{ Escherichia coli } \\
\hline DH5 $\alpha$ & $\mathrm{F}^{\prime}$ recA, N80dlacZ, $\triangle M 15$ & Stratagene \\
\hline XL1-Blue MRF' & $F^{\prime}$ proAB lacI ${ }^{\mathrm{q}} Z \Delta M 15 \operatorname{Tn} 10\left(\mathrm{Tet}^{\mathrm{r}}\right)$ & Stratagene \\
\hline \multicolumn{3}{|c|}{ Xanthomonas oryzae pv. oryzae } \\
\hline $\mathrm{PXO} 99^{\mathrm{A}}$ & Philippine race 6; azacytidine resistant clone of PXO99 & Hopkins et al. 1992 \\
\hline ME7 & PXO99 ${ }^{\mathrm{A}}$ with the mutation of $\mathrm{HrpC}$ & Zhu et al. 2000 \\
\hline MX6, MX15 & PXO99A with one copy of $X o p Z_{P X O 99}$ deleted & This study \\
\hline MX1, MX24 & PXO99 ${ }^{\mathrm{A}}$ with two copies of $X o p Z_{P X O 99}$ deleted & This study \\
\hline
\end{tabular}

${ }^{\mathrm{a}} \mathrm{NPTII}=$ neomycin phosphotransferase II; $\mathrm{Tet}^{\mathrm{r}}=$ tetracycline resistance. 
used to amplify the kanamycin resistance $\left(\mathrm{Kn}^{\mathrm{r}}\right)$ cassette from pKD13 (Datsenko and Wanner 2000). The forward primer of Frag1 and Kn-R were used together with the amplicon Frag1 and the $\mathrm{Kn}^{\mathrm{r}}$ cartridge as templates to amplify a PCR product that contained both the Frag1 and the $\mathrm{Kn}^{\mathrm{r}}$ cartridge, whereas the primers $\mathrm{Kn}-\mathrm{F}$ and the reverse primer of Frag2 were used with the $\mathrm{Kn}^{\mathrm{r}}$ cartridge and the amplicon Frag2 to produce a different PCR product that contained the $\mathrm{Kn}^{\mathrm{r}}$ cartridge and the Frag2. These two PCR products were then used together as templates for another round of PCR using the Frag1 forward and Frag2 reverse primers. The final PCR product was cloned into pGEM-T vector (Promega Corp.) and confirmed with multiple restriction digestions or sequencing analysis. The plasmid DNA was transformed into PXO99 ${ }^{\mathrm{A}}$ by electroporation. The kanamycin-resistant and ampicillin-sensitive clones were selected for further molecular and genetic characterization of confirmation. For confirmation of mutation, two PCR reactions were performed. The first PCR involved amplifying the alleles of the target gene from the genomic DNA of the mutant and the wild-type strain PXO99 ${ }^{\mathrm{A}}$ by using the Frag1 forward and Frag2 reverse primers. The second PCR involved the amplification of an internal region using primers for each target gene. The PCR products were subjected to agarose gel electrophoresis.

\section{RNA isolation and quantitative RT-PCR.}

Bacteria were cultured at $28^{\circ} \mathrm{C}$ with shaking at $200 \mathrm{rpm}$ in NB (Difco Laboratories) or XOM2 medium (Tsuge et al. 2002). XOM 2 contained xylose $(0.18 \%)$, D,L-methionine (670 $\mu \mathrm{M})$, sodium $\mathrm{L}(+)$-glutamate $(10 \mathrm{mM}), \mathrm{KH}_{2} \mathrm{PO}_{4}(14.7 \mathrm{mM})$, $\mathrm{MnSO}_{4}(40 \mu \mathrm{M}), \mathrm{Fe}(\mathrm{III})-\mathrm{EDTA}(240 \mu \mathrm{M})$, and $\mathrm{MgCl}_{2}(5 \mathrm{mM})$, $\mathrm{pH}$ 6.5. Strains were initiated in $2 \mathrm{ml}$ of $\mathrm{NB}$ and grown to an optical density of 0.2 at $600 \mathrm{~nm}$. Half of the cells was harvested, washed twice with XOM2, and grown in XOM2 for approximately $12 \mathrm{~h}$. The other half was simultaneously grown in the NB medium. The cells were then harvested and washed twice prior to RNA extraction. Total bacterial RNA was extracted by using TRI reagent (Ambion, Austin, TX, U.S.A.) according to the instructions of the manufacturer. Total RNA $(1 \mu \mathrm{g})$ was treated with DNase I (Invitrogen, Carlsbad, CA, U.S.A.) to eliminate the DNA contamination and used for cDNA synthesis by using the random 9-mers and AccuSscript High Fidelity First Strand cDNA Synthesis kit (Stratagene, La Jolla, CA, U.S.A.) following the user's manual. cDNA derived from $50 \mathrm{ng}$ of RNA was used for each reaction of semiquantitative PCR (semi-qPCR). Semi-qPCR for $X o p Z_{P X O 99}$ gene expression was performed by using gene-specific primers XopZin-F and XopZin-R. Ribosomal 16S RNA expression was used as an internal control with the gene-specific primers 16SrRNA-F and 16SrRNA-R.

\section{Virulence assays.}

Rice cv. IR24 (susceptible to PXO99 ${ }^{\mathrm{A}}$ ) was grown in a growth chamber set at $28^{\circ} \mathrm{C}$ with a 12 -h photoperiod and $85 \%$ humidity. The fully expanded leaves of 4 -week-old rice plants were inoculated with strains indicated in the text by the leaf-clipping method (Kauffman et al. 1973). The bacterial inoculum concentrations were adjusted to an optical density of 0.5 at $600 \mathrm{~nm}$ (approximately $0.5 \times 10^{8} \mathrm{CFU} / \mathrm{ml}$ ) using a BioPhotomer (Eppendorf AG, Hamburg, Germany). Symptoms (grayish to chlorotic coloration moving down the inoculated leaf along the main vein from the cut tip) were scored by measuring lesion length 12 days after inoculation. After lesion lengths were measured, the leaves from each treatment were pooled and cut into small (approximately 1 $\mathrm{cm})$ pieces and ground in water $(1 \mathrm{ml}$ per leaf) using a sterilized mortar and pestle. The resulting suspension was diluted serially and plated in triplicate on TS agar with appropriate antibiotics. Counts were taken from appropriate dilutions on the three plates and converted into CFU per leaf. One-way analysis of variance (ANOVA) statistical analyses were performed on all measurements. The Tukey honest significant difference test was used for post-ANOVA pairwise tests for significance, set at $5 \%(P<0.5)$.

\section{Functional complementation of $X o p Z_{P X o g g}$ mutants.}

A 6,303-bp genomic region spanning $X o p Z_{P X O 99}$ was PCR amplified by using primers XopZg-F and XopZg-R. The PCR product was cloned into pGEM-T and confirmed with multiple restriction digestions and partial sequencing. The $X o p Z_{P X O 99}$ DNA was cut with BamHI and cloned into pHM1, resulting in the plasmid pXopZg. Similarly, the predicted ORF of $X o p Z_{P X O 99}$ was PCR amplified using primers XopZc-F and XopZc-R and cloned into pGEM-T. BamHI and XhoI, whose restriction sites were incorporated into XopZc-F and XopZc$\mathrm{R}$, respectively, were used to move $X_{0 p Z_{P X O 99}}$ into $\mathrm{pBY} 301$ that was digested with BamHI and SalI, resulting in pBYXopZc. pBY301 is a pGEM-T-derived plasmid containing the promoter of the NPTII gene from pENTR4 (Invitrogen) (B. Yang, unpublished). In pBY-XopZc, the ORF of XopZ $Z_{P X O 99}$ was under control of the NPTII promoter. The expression cassette of $X o p Z_{P X O 99}$ was cut with $B g l I I$ and cloned into the BamHI-digested pHM1, resulting in pXopZc. PXO99 ${ }^{\mathrm{A}} \mathrm{mu}-$ tants ME1 and ME24 were each used as the recipients for plasmids pXopZg and pXopZc. The respective transformants were inoculated on IR24 plants by leaf-clipping inoculation along with PXO99 ${ }^{\mathrm{A}}$ and the mutants.

\section{Phylogenetic analysis of XopZ family.}

Phylogenetic analysis of the aligned full-length sequences was conducted with MEGA 3.1 (Kumar et al. 2004) using neighbor joining (Saitou and Nei 1987) and the Poisson correction model. Pairwise deletion was used for handling of sequence gaps, and 1,000 bootstrap replicates were performed. Members of the XopZ effector family used for phylogenesis analysis are indicated as locus tag followed by its origin and reference: XAC2009, X. axonopodis pv. citri 306 (da Silva et al. 2002); XCV2059, X. campestris pv. vesicatoria 85-10 (Thieme et al. 2005); XCC1975, X. campestris pv. campestris ATCC 33913 (da Silva et al. 2002); XC_2210, X. campestris pv. campestris 8004 (Qian et al. 2005); Xcc-b100_2274, X. campestris pv. campestris B100 (Vorholter et al. 2008); XOO2543, X. oryzae pv. oryzae KACC10331 (Lee et al. 2005); XOO2402, X. oryzae pv. oryzae MAFF 311018 (Ochiai et al. 2005); PXO_01041 and PXO_06125, X. oryzae pv. oryzae PXO99 (Salzberg et al. 2008); Xoc_11725, X. oryzae pv. oryzicola BLS256 (The National Center for Biotechnology Information [NCBI] accession number AAQN00000000); Aave_2261, A. citrulli AAC00-1 (Copeland et al. direct submission); PSPPH_4736, P. syringae pv. phaseolicola 1448A (Joardar et al. 2005); PSPTOT1_1672, P. syringae pv. tomato T1 (Almeida et al. 2009); RSp1024, RSp0847, and RSp0846, $R$. solanacearum GMI1000 (Salanoubat et al. 2002); RRSL_01071 and RRSL_00546, $R$. solanacearum UW551 (Gabriel et al. 2006); RSMK03047 and RSMK00806, R. solanacearum MolK2 (NCBI accession number NS_000197); RSIPO_04049, and RSIPO_01281, R. solanacearum IPO1609 (NCBI accession number CU914166).

\section{ACKNOWLEDGMENTS}

We thank F. White for critical reading of the manuscript and G. Beattie and $\mathrm{Z}$. Chen for help with the technique of gene deletion and replacement. This work was supported by the faculty start-up funds of Iowa State Uni- 
versity and a grant from the National Science Foundation Plant Genome Research Project (award number 0820831 to B. Yang) and by a scholarship from the China Scholarship Council (to C. Song).

\section{LITERATURE CITED}

Almeida, N. F., Yan, S., Lindeberg, M., Studholme, D. J., Schneider, D. J., Condon, B., Liu, H., Viana, C. J., Warren, A., Evans, C., Kemen, E., Maclean, D., Angot, A., Martin, G. B., Jones, J. D., Collmer, A., Setubal, J. C., and Vinatzer, B. A. 2009. A draft genome sequence of Pseudomonas syringae pv. tomato T1 reveals a type III effector repertoire significantly divergent from that of Pseudomonas syringae pv. tomato DC3000. Mol. Plant-Microbe Interact. 22:52-62.

Ausubel, F., Brent, R., Kingston, R., Moore, D., Seidman, J., and Struhl, K. 1993. Current Protocols in Molecular Biology, 1st ed. John Wiley and Sons, New York.

Bartetzko, V., Sonnewald, S., Vogel, F., Hartner, K., Stadler, R., Hammes, U. Z., and Bornke, F. 2009. The Xanthomonas campestris pv. vesicatoria type III effector protein XopJ inhibits protein secretion: Evidence for interference with cell wall-associated defense responses. Mol. PlantMicrobe Interact. 22:655-664.

Block, A., Li, G., Fu, Z. Q., and Alfano, J. R. 2008. Phytopathogen type III effector weaponry and their plant targets. Curr. Opin. Plant Biol. 11:396-403.

Boch, J., Scholze, H., Schornack, S., Landgraf, A., Hahn, S., Kay, S., Lahaye, T., Nickstadt, A., and Bonas, U. 2009. Breaking the code of DNA binding specificity of TAL-type III effectors. Science 326:15091512.

Boller, T., and Felix, G. 2009. A renaissance of elicitors: Perception of microbe-associated molecular patterns and danger signals by patternrecognition receptors. Annu. Rev. Plant. Biol. 60:379-406.

Buttner, D., and Bonas, U. 2002. Getting across-bacterial type III effector proteins on their way to the plant cell. EMBO (Eur. Mol. Biol. Organ.) J. 21:5313-5322.

Buttner, D., and Bonas, U. 2006. Who comes first? How plant pathogenic bacteria orchestrate type III secretion. Curr. Opin. Microbiol. 9:193-200.

Buttner, D., and He, S. Y. 2009. Type III protein secretion in plant pathogenic bacteria. Plant Physiol. 150:1656-1664.

Castaneda, A., Reddy, J. D., El-Yacoubi, B., and Gabriel, D. W. 2005. Mutagenesis of all eight $a v r$ genes in Xanthomonas campestris pv. campestris had no detected effect on pathogenicity, but one avr gene affected race specificity. Mol. Plant-Microbe Interact. 18:1306-1317.

Chisholm, S. T., Coaker, G., Day, B., and Staskawicz, B. J. 2006. Hostmicrobe interactions: Shaping the evolution of the plant immune response. Cell 124:803-814.

Cho, H. J., Park, Y. J., Noh, T. H., Kim, Y. T., Kim, J. G., Song, E. S., Lee, D. H., and Lee, B. M. 2008. Molecular analysis of the hrp gene cluster in Xanthomonas oryzae pathovar oryzae KACC10859. Microb. Pathog. 44:473-483.

Cunnac, S., Occhialini, A., Barberis, P., Boucher, C., and Genin, S. 2004 Inventory and functional analysis of the large Hrp regulon in Ralstonia solanacearum: Identification of novel effector proteins translocated to plant host cells through the type III secretion system. Mol. Microbiol. 53:115-128.

Cunnac, S., Lindeberg, M., and Collmer, A. 2009. Pseudomonas syringae type III secretion system effectors: Repertoires in search of functions. Curr. Opin. Microbiol. 12:53-60.

da Cunha, L., Sreerekha, M. V., and Mackey, D. 2007. Defense suppression by virulence effectors of bacterial phytopathogens. Curr. Opin. Plant Biol. 10:349-357.

da Silva, A. C., Ferro, J. A., Reinach, F. C., Farah, C. S., Furlan, L. R., Quaggio, R. B., Monteiro-Vitorello, C. B., Van Sluys, M. A., Almeida, N. F., Alves, L. M., do Amaral, A. M., Bertolini, M. C., Camargo, L. E., Camarotte, G., Cannavan, F., Cardozo, J., Chambergo, F., Ciapina, L. P., Cicarelli, R. M., Coutinho, L. L., Cursino-Santos, J. R., El-Dorry, H., Faria, J. B., Ferreira, A. J., Ferreira, R. C., Ferro, M. I., Formighieri, E. F., Franco, M. C., Greggio, C. C., Gruber, A., Katsuyama, A. M., Kishi, L. T., Leite, R. P., Lemos, E. G., Lemos, M. V., Locali, E. C., Machado, M. A., Madeira, A. M., Martinez-Rossi, N. M., Martins, E. C., Meidanis, J., Menck, C. F., Miyaki, C. Y., Moon, D. H., Moreira, L. M., Novo, M. T., Okura, V. K., Oliveira, M. C., Oliveira, V. R., Pereira, H. A., Rossi, A., Sena, J. A., Silva, C., de Souza, R. F., Spinola, L. A., Takita, M. A., Tamura, R. E., Teixeira, E. C., Tezza, R. I., Trindade dos Santos, M., Truffi, D., Tsai, S. M., White, F. F., Setubal, J. C., and Kitajima, J. P. 2002. Comparison of the genomes of two Xanthomonas pathogens with differing host specificities. Nature 417:459-463.

Datsenko, K. A., and Wanner, B. L. 2000. One-step inactivation of chromosomal genes in Escherichia coli $\mathrm{K}-12$ using PCR products. Proc. Natl. Acad. Sci. U.S.A. 97:6640-6645.
Ding, X., Richter, T., Chen, M., Fujii, H., Seo, Y. S., Xie, M., Zheng, X. Kanrar, S., Stevenson, R. A., Dardick, C., Li, Y., Jiang, H., Zhang, Y., Yu, F., Bartley, L. E., Chern, M., Bart, R., Chen, X., Zhu, L., Farmerie, W. G., Gribskov, M., Zhu, J. K., Fromm, M. E., Ronald, P. C., and Song, W. Y. 2009. A rice kinase-protein interaction map. Plant Physiol. 149:1478-1492.

Furutani, A., Takaoka, M., Sanada, H., Noguchi, Y., Oku, T., Tsuno, K., Ochiai, H., and Tsuge, S. 2009. Identification of novel type III secretion effectors in Xanthomonas oryzae pv. oryzae. Mol. Plant-Microbe Interact. 22:96-106.

Gabriel, D. W., Allen, C., Schell, M., Denny, T. P., Greenberg, J. T., Duan, Y. P., Flores-Cruz, Z., Huang, Q., Clifford, J. M., Presting, G., Gonzalez, E. T., Reddy, J., Elphinstone, J., Swanson, J., Yao, J., Mulholland, V., Liu, L., Farmerie, W., Patnaikuni, M., Balogh, B., Norman, D., Alvarez, A., Castillo, J. A., Jones, J., Saddler, G., Walunas, T., Zhukov, A., and Mikhailova, N. 2006. Identification of open reading frames unique to a select agent: Ralstonia solanacearum race 3 biovar 2. Mol. Plant-Microbe Interact. 19:69-79.

Gassmann, W., Dahlbeck, D., Chesnokova, O., Minsavage, G. V., Jones, J. B., and Staskawicz, B. J. 2000. Molecular evolution of virulence in natural field strains of Xanthomonas campestris pv. vesicatoria. J. Bacteriol. 182:7053-7059.

Grant, S. R., Fisher, E. J., Chang, J. H., Mole, B. M., and Dangl, J. L. 2006. Subterfuge and manipulation: Type III effector proteins of phytopathogenic bacteria. Annu. Rev. Microbiol. 60:425-449.

Gu, K., Yang, B., Tian, D., Wu, L., Wang, D., Sreekala, C., Yang, F., Chu, Z., Wang, G. L., White, F. F., and Yin, Z. 2005. $R$ gene expression induced by a type-III effector triggers disease resistance in rice. Nature 435:1122-1125

Guo, M., Tian, F., Wamboldt, Y., and Alfano, J. R. 2009. The majority of the type III effector inventory of Pseudomonas syringae pv. tomato DC3000 can suppress plant immunity. Mol. Plant-Microbe Interact. 22:1069-1080.

Gurlebeck, D., Thieme, F., and Bonas, U. 2006. Type III effector proteins from the plant pathogen Xanthomonas and their role in the interaction with the host plant. J. Plant Physiol. 163:233-255.

Guttman, D. S., Vinatzer, B. A., Sarkar, S. F., Ranall, M. V., Kettler, G., and Greenberg, J. T. 2002. A functional screen for the type III (Hrp) secretome of the plant pathogen Pseudomonas syringae. Science 295:1722-1726.

Hopkins, C. M., White, F. F., Choi, S. H., Guo, A., and Leach, J. E. 1992. Identification of a family of avirulence genes from Xanthomonas oryzae pv. oryzae. Mol. Plant-Microbe Interact. 5:451-459.

Hotson, A., Chosed, R., Shu, H., Orth, K., and Mudgett, M. B. 2003. Xanthomonas type III effector XopD targets SUMO-conjugated proteins in planta. Mol. Microbiol. 50:377-389.

Jiang, B. L., He, Y. Q., Cen, W. J., Wei, H. Y., Jiang, G. F., Jiang, W., Hang, X. H., Feng, J. X., Lu, G. T., Tang, D. J., and Tang, J. L. 2008 The type III secretion effector XopXccN of Xanthomonas campestris pv. campestris is required for full virulence. Res. Microbiol. 159:216220.

Joardar, V., Lindeberg, M., Jackson, R. W., Selengut, J., Dodson, R., Brinkac, L. M., Daugherty, S. C., Deboy, R., Durkin, A. S., Giglio, M. G., Madupu, R., Nelson, W. C., Rosovitz, M. J., Sullivan, S., Crabtree, J., Creasy, T., Davidsen, T., Haft, D. H., Zafar, N., Zhou, L., Halpin, R. Holley, T., Khouri, H., Feldblyum, T., White, O., Fraser, C. M., Chatterjee, A. K., Cartinhour, S., Schneider, D. J., Mansfield, J., Collmer, A., and Buell, C. R. 2005. Whole-genome sequence analysis of Pseudomonas syringae pv. phaseolicola 1448A reveals divergence among pathovars in genes involved in virulence and transposition. J. Bacteriol. 187:6488-6498.

Kauffman, H. E., Reddy, A. P. K., Hsiek, S. P., and Marca, S. D. 1973. An improved technique for evaluating resistance of race varieties to Xanthomonas oryza. Plant Dis. Rep. 57:537-541.

Kay, S., Hahn, S., Marois, E., Hause, G., and Bonas, U. 2007. A bacterial effector acts as a plant transcription factor and induces a cell size regulator. Science 318:648-651.

Kearney, B., and Staskawicz, B. J. 1990. Widespread distribution and fitness contribution of Xanthomonas campestris avirulence gene avrBs2. Nature 346:385-386.

Keshavarzi, M., Soylu, S., Brown, I., Bonas, U., Nicole, M., Rossiter, J., and Mansfield, J. 2004. Basal defenses induced in pepper by lipopolysaccharides are suppressed by Xanthomonas campestris pv. vesicatoria. Mol. Plant-Microbe Interact. 17:805-815.

Kim, J. G., Taylor, K. W., Hotson, A., Keegan, M., Schmelz, E. A., and Mudgett, M. B. 2008. XopD SUMO protease affects host transcription, promotes pathogen growth, and delays symptom development in Xanthomonas-infected tomato leaves. Plant Cell 20:1915-1929.

Kim, J. G., Li, X., Roden, J. A., Taylor, K. W., Aakre, C. D., Su, B., Lalonde, S., Kirik, A., Chen, Y., Baranage, G., McLane, H., Martin, G. 
B., and Mudgett, M. B. 2009. Xanthomonas T3S effector XopN suppresses PAMP-triggered immunity and interacts with a tomato atypical receptor-like kinase and TFT1. Plant Cell 21:1305-1323.

Kumar, S., Tamura, K., and Nei, M. 2004. MEGA3: Integrated software for molecular evolutionary genetics analysis and sequence alignment. Brief Bioinform. 5:150-163.

Kvitko, B. H., Park, D. H., Velasquez, A. C., Wei, C. F., Russell, A. B., Martin, G. B., Schneider, D. J., and Collmer, A. 2009. Deletions in the repertoire of Pseudomonas syringae pv. tomato DC3000 type III secretion effector genes reveal functional overlap among effectors. PLoS Pathog. 5:e1000388.

Lee, B. M., Park, Y. J., Park, D. S., Kang, H. W., Kim, J. G., Song, E. S., Park, I. C., Yoon, U. H., Hahn, J. H., Koo, B. S., Lee, G. B., Kim, H., Park, H. S., Yoon, K. O., Kim, J. H., Jung, C. H., Koh, N. H., Seo, J. S., and Go, S. J. 2005. The genome sequence of Xanthomonas oryzae pathovar oryzae KACC10331, the bacterial blight pathogen of rice. Nucleic Acids Res. 33:577-586

Lee, S. W., Han, S. W., Sririyanum, M., Park, C. J., Seo, Y. S., and Ronald, P. C. 2009. A type I-secreted, sulfated peptide triggers XA21-mediated innate immunity. Science 326:850-853.

Mazzola, M., Leach, J. E., Nelson, R., and White, F. F. 1994. Analysis of the interaction between Xanthomonas oryzae pv. oryzae and the rice cultivars IR24 and IRBB21. Phytopathology 84:392-397.

Metz, M., Dahlbeck, D., Morales, C. Q., Al Sady, B., Clark, E. T., and Staskawicz, B. J. 2005. The conserved Xanthomonas campestris pv. vesicatoria effector protein $\mathrm{XopX}$ is a virulence factor and suppresses host defense in Nicotiana benthamiana. Plant J. 41:801-814.

Mew, T. W. 1987. Current status and future prospects of research on bacterial blight of rice. Annu. Rev. Phytopathol. 25:359-382.

Moscou, M. J., and Bogdanove, A. J. 2009. A simple cipher governs DNA recognition by TAL effectors. Science 326:1501.

Mudgett, M. B. 2005. New insights to the function of phytopathogenic bacterial type III effectors in plants. Annu. Rev. Plant. Biol. 56:509531

Ochiai, H., Inoue, Y., Takeya, M., Sasaki, A., and Kaku, H. 2005.Genome sequence of Xanthomonas oryzae pv. oryzae suggests contribution of large numbers of effector genes and insertion sequences to its race diversity. Jpn. Agric. Res. Q. 39:275-287.

Qian, W., Jia, Y., Ren, S. X., He, Y. Q., Feng, J. X., Lu, L. F., Sun, Q. Ying, G., Tang, D. J., Tang, H., Wu, W., Hao, P., Wang, L., Jiang, B. L., Zeng, S., Gu, W. Y., Lu, G., Rong, L., Tian, Y., Yao, Z., Fu, G., Chen, B., Fang, R., Qiang, B., Chen, Z., Zhao, G. P., Tang, J. L., and He, C. 2005. Comparative and functional genomic analyses of the pathogenicity of phytopathogen Xanthomonas campestris pv. campestris. Genome Res. 15:757-767.

Roden, J. A., Belt, B., Ross, J. B., Tachibana, T., Vargas, J., and Mudgett, M. B. 2004. A genetic screen to isolate type III effectors translocated into pepper cells during Xanthomonas infection. Proc. Natl. Acad. Sci. U.S.A. 101:16624-16629.

Romer, P., Hahn, S., Jordan, T., Strauss, T., Bonas, U., and Lahaye, T. 2007. Plant pathogen recognition mediated by promoter activation of the pepper Bs3 resistance gene. Science 318:645-648.

Saitou, N., and Nei, M. 1987.The neighbor-joining method: A new method for reconstructing phylogenetic trees. Mol. Biol. Evol. 4:406-425.

Salanoubat, M., Genin, S., Artiguenave, F., Gouzy, J., Mangenot, S., Arlat, M., Billault, A., Brottier, P., Camus, J. C., Cattolico, L., Chandler, M., Choisne, N., Claudel-Renard, C., Cunnac, S., Demange, N., Gaspin, C., Lavie, M., Moisan, A., Robert, C., Saurin, W., Schiex, T., Siguier, P., Thebault, P., Whalen, M., Wincker, P., Levy, M., Weissenbach, J., and Boucher, C. A. 2002. Genome sequence of the plant pathogen Ralstonia solanacearum. Nature 415:497-502.

Salzberg, S. L., Sommer, D. D., Schatz, M. C., Phillippy, A. M., Rabinowicz, P. D., Tsuge, S., Furutani, A., Ochiai, H., Delcher, A. L., Kelley, D., Madupu, R., Puiu, D., Radune, D., Shumway, M., Trapnell,
C., Aparna, G., Jha, G., Pandey, A., Patil, P. B., Ishihara, H., Meyer, D. F., Szurek, B., Verdier, V., Koebnik, R., Dow, J. M., Ryan, R. P., Hirata, H., Tsuyumu, S., Won Lee, S., Seo, Y. S., Sriariyanum, M., Ronald, P. C., Sonti, R. V., Van Sluys, M. A., Leach, J. E., White, F. F., and Bogdanove, A. J. 2008. Genome sequence and rapid evolution of the rice pathogen Xanthomonas oryzae pv. oryzae PXO99 ${ }^{\mathrm{A}}$. BMC Genomics 9:204.

Sugio, A., Yang, B., Zhu, T., and White, F. F. 2007. Two type III effector genes of Xanthomonas oryzae pv. oryzae control the induction of the host genes $O S T F I I A \gamma 1$ and $O s T F X 1$ during bacterial blight of rice. Proc. Natl. Acad. Sci. U.S.A. 104:10720-10725.

Takai, R., Isogai, A., Takayama, S., and Che, F. S. 2008. Analysis of flagellin perception mediated by flg22 receptor OsFLS2 in rice. Mol. PlantMicrobe Interact. 21:1635-1642.

Thieme, F., Koebnik, R., Bekel, T., Berger, C., Boch, J., Buttner, D., Caldana, C., Gaigalat, L., Goesmann, A., Kay, S., Kirchner, O., Lanz, C., Linke, B., McHardy, A. C., Meyer, F., Mittenhuber, G., Nies, D. H., Niesbach-Klosgen, U., Patschkowski, T., Ruckert, C., Rupp, O., Schneiker, S., Schuster, S. C., Vorholter, F. J., Weber, E., Puhler, A., Bonas, U., Bartels, D., and Kaiser, O. 2005. Insights into genome plasticity and pathogenicity of the plant pathogenic bacterium Xanthomonas campestris pv. vesicatoria revealed by the complete genome sequence. J. Bacteriol. 187:7254-7266.

Tsuge, S., Fukunaka, R., Oku, T., Tsuno, K., Ochiai, H., Inoue, Y., Kaku, H., and Kubo, Y. 2002. Expression of Xanthomonas oryzae pv. oryzae hrp genes in XOM2, a novel synthetic medium. J. Gen. Plant Pathol. 68:363-371.

Vorholter, F. J., Schneiker, S., Goesmann, A., Krause, L., Bekel, T., Kaiser, O., Linke, B., Patschkowski, T., Ruckert, C., Schmid, J., Sidhu, V. K., Sieber, V., Tauch, A., Watt, S. A., Weisshaar, B., Becker, A., Niehaus, K., and Puhler, A. 2008. The genome of Xanthomonas campestris pv. campestris B100 and its use for the reconstruction of metabolic pathways involved in xanthan biosynthesis. J. Biotechnol. 134:33-45.

Wang, C. L., Xu, A., Gao, Y., Fan, Y. L., Liang, Y. T., Zheng, C. K., Sun, L. Q., Wang, W. Q., and Zhao, K. J. 2008. Generation and characterisation of Tn5-tagged Xanthomonas oryzae pv. oryzae mutants that overcome Xa23 -mediated resistance to bacterial blight of rice. Eur. J. Plant Pathol. 123:343-351.

White, F. F., and Yang, B. 2009. Host and pathogen factors controlling the rice-Xanthomonas oryzae interaction. Plant Physiol. 150:1677-1686.

White, F. F., Potnis, N., Jones, J. B., and Koebnik, R. 2009. The type III effectors of Xanthomonas. Mol. Plant. Pathol. 10:749-766.

Wichmann, G., and Bergelson, J. 2004. Effector genes of Xanthomonas axonopodis pv. vesicatoria promote transmission and enhance other fitness traits in the field. Genetics 166:693-706.

Willems, A., Goor, M., Thielemans, S., Gillis, M., Kersters, K., and De Ley, J. 1992. Transfer of several phytopathogenic Pseudomonas species to Acidovorax as Acidovorax avenae subsp. avenae subsp. nov., comb. nov., Acidovorax avenae subsp. citrulli, Acidovorax avenae subsp. cattleyae, and Acidovorax konjaci. Int. J. Syst. Bacteriol. 42:107-119.

Yang, B., and White, F. F. 2004. Diverse members of the AvrBs3/PthA family of type III effectors are major virulence determinants in bacterial blight disease of rice. Mol. Plant-Microbe Interact. 17:1192-1200.

Yang, B., Sugio, A., and White, F. F. 2006. Os $8 N 3$ is a host disease-susceptibility gene for bacterial blight of rice. Proc. Natl. Acad. Sci. U.S.A. 103:10503-10508.

Zhu, W., MaGbanua, M. M., and White, F. F. 2000. Identification of two novel hrp-associated genes in the hrp gene cluster of Xanthomonas oryzae pv. oryzae. J. Bacteriol. 182:1844-1853.

\section{AUTHOR-RECOMMENDED INTERNET RESOURCE}

The Xanthomonas Resource: www.xanthomonas.org/t3e.html 